\title{
Recenzja
}

\section{Formy odpowiedzialności konstytucyjnej w państwach europejskich, pod red. Sabiny Grabowskiej, Radosława Grabowskiego, \\ Wydawnictwo Adam Marszałek, Toruń 2010, ss. 482}

Odpowiedzialność osób zajmujących najważniejsze stanowiska w państwie jest gwarancją praworządności we współczesnych państwach demokratycznych. Bowiem jak wskazuje praktyka na każdym, kto jest dysponentem władzy publicznej, ciąży pokusa jej nadużywania ${ }^{1}$. Odpowiedzialność władzy należy do kanonów współczesnych demokracji, wynika $\mathrm{z}$ istoty i założeń demokratycznego państwa prawnego, jest częścią demokratycznych mechanizmów sprawowania władzy. Dlatego za cenne, aktualne i właściwe należy uznać podjęcie, w recenzowanym opracowaniu, problematyki odpowiedzialności konstytucyjnej. Inicjatywa ta jest tym cenniejsza, bo ten problem, mimo że doczekał się wielu publikacji, nie został jeszcze potraktowany tak kompleksowo i wyczerpująco jednocześnie.

Recenzowana publikacja stanowi kontynuację przedsięwzięć podejmowanych przez jej Autorów, a przede wszystkim redaktorów - Sabinę i Radosława Grabowskich. Wcześniej ukazały się, pod Ich redakcją, zbiorowe opracowania problematyki sposobu wyboru prezydenta oraz zasad zmian konstytucji w państwach europejskich ${ }^{2}$, obecnie podjęli nową tematykę odpowiedzialności konstytucyjnej. Podobnie jak w poprzednich przypadkach i to opracowanie ma charakter przekrojowy, obejmujący całość analizowanej materii.

Za szczególnie godne odnotowania uważam uwzględnienie w opracowaniu rozwiązań zastosowanych we wszystkich państwach Europy. Jak podkreślili redaktorzy we wstępie ujęcie takie ma na celu przełamanie schematu, polegającego na prezentacji regulacji zastosowanych w wybranych

$1 \quad$ M. Kowalska, Organy wtadzy sądowniczej, [w:] Organy wtadzy publicznej wświetle Konstytucji Rzeczypospolitej Polskiej z 2 kwietnia 1997 r., pod red. Z. Szeligi, Lublin 2006, s. 181.

${ }_{2}$ Prawo wyborcze na urząd prezydenta w państwach europejskich, pod red. S. Grabowskiej, R. Grabowskiego, Warszawa 2007; Zasady zmiany konstytucji w państwach europejskich, pod red. R. Grabowskiego, S. Grabowskiej, Warszawa 2008. 
państwach Europy oraz pokazanie różnorodności przyjmowanych unormowań. Koncepcja ta wydaje się trafna i przekonywująca, bowiem rzeczywiście zwykle analizowane są systemy i instytucje reprezentatywnych państw Europy (Wielkiej Brytanii, Francji, Niemiec czy Rosji), a pomijane pozostałe. Ujęcie w opracowaniu wszystkich państw europejskich dostarcza wiedzy o zwykle niedocenianych, a często oryginalnych rozwiązaniach przyjmowanych w mniej reprezentatywnych i mniejszych państwach.

Opracowanie składa się więc z 47 rozdziałów, w których przedstawione zostały tytułowe formy odpowiedzialności konstytucyjnej w państwach Europy. Podzielone zostało na dwie części - republiki i monarchie europejskie (ujęte w porządku alfabetycznym), co znajduje uzasadnienie w odmiennych zasadach dotyczących odpowiedzialności konstytucyjnej głowy państwa. Przyjęty podział jest jasny i klarowny, choć pozostawia pewien niedosyt. Bardziej interesujące, choć niewątpliwie skomplikowane, kontrowersyjne i trudne do przeprowadzenia, byłoby podejście modelowe, oparte na wyodrębnieniu rozwiązań charakterystycznych dla pewnych grup państw (np. model anglosaski, romański) i próbie przyporządkowania pozostałych do zaproponowanych modeli.

Pewne zastrzeżenia budzą kwestie terminologiczne. Tytułowa odpowiedzialność konstytucyjna nie jest pojęciem rozumianym jednoznacznie i jednolicie ${ }^{3}$. Redaktorzy recenzowanej pracy uznali za odpowiedzialność konstytucyjną, co wyrazili we wstępie, wszystkie przypadki, w których podmiot ponosi odpowiedzialność za naruszenie konstytucji. Definicja ta wydaje się zbyt ograniczona $\mathrm{w}$ stosunku do podejmowanych $\mathrm{w}$ recenzowanej książce treści, gdyż tam została potraktowana jako odpowiedzialność za naruszenie norm powszechnie obowiązujących. W poszczególnych rozdziałach można więc odnaleźć rozważania dotyczące odpowiedzialności cywilnej, karnej, konstytucyjnej sensu stricto, a nawet politycznej. Wątpliwości i rozbieżności terminologicznych nie rozwiązuje rozdział pierwszy, teoretyczny, dotyczący pojęcia oraz rodzajów odpowiedzialności konstytucyjnej. Sam w sobie rozdział ten jest rzetelnie napisany i niewątpliwie interesujący, szczególnie

3 Na temat rozumienia pojęcia odpowiedzialność konstytucyjna zob. m.in. M. Pietrzak, Odpowiedzialność konstytucyjna w Polsce, Warszawa 1992, s. 38; B. Banaszak, Porównawcze prawo konstytucyjne wspótczesnych państw demokratycznych, Warszawa 2007, s. 339-341; Z. Szeliga, Odpowiedzialność parlamentarzystów, prezydenta, Rady Ministrów oraz jej członków w świetle Konstytucji RP z 2 kwietnia 1997 r., Lublin 2003, s. 7-9. 
w kontekście osoby Autora Jana Filipa, co pozwala na ukazanie czeskiego spojrzenia na problematykę, którego specyfika polega m.in. na wyróżnieniu formy odpowiedzialności prawnej i pozaprawnej, czy próbie skorygowania twierdzenia, że odpowiedzialność karna powstała przed polityczną.

Cechą charakterystyczną recenzowanej publikacji jest metodologiczna klarowność struktury publikacji i ścisłe przestrzeganie przyjętych reguł wewnętrznego podziału treści. Każdy rozdział składa się z podobnych części wewnętrznych, co decyduje o przejrzystości i umożliwia dokonywanie porównań poszczególnych kwestii. W „uwagach ogólnych” przedstawione zostało kształtowanie się instytucji odpowiedzialności konstytucyjnej w poszczególnych państwach, od początku jej wprowadzenia po wskazanie aktów stanowiących podstawę jej obecnego obowiązywania. Główną tezą, postawioną na podstawie tych części, jest twierdzenie o kontynuacji przyjmowanych regulacji. Można zauważyć, że zwykle w poszczególnych państwach zachowywano sprawdzone instytucje, uzupełniając je o nowe rozwiązania, stanowiące zdobycze rozwoju europejskiego konstytucjonalizmu. Można także zaobserwować recepcję rozwiązań skutecznie funkcjonujących w innych, zwykle sąsiednich, państwach. Następnie, w każdym rozdziale, zawarte są rozważania dotyczące odpowiedzialności konstytucyjnej głowy państwa oraz pozostałych podmiotów odpowiedzialności konstytucyjnej (zwykle członków rządu), a także procedury egzekwowania tej odpowiedzialności. Zdecydowaną większość rozdziałów cechuje kompetentna i solidna prezentacja zagadnień, zwarty i przejrzysty tok narracji.

Ze względu na liczbę rozdziałów oraz ramy niniejszej recenzji nie jest możliwe przedstawienie merytorycznej strony każdej z części, ale należy sformułować kilka ogólnych uwag. Po pierwsze trzeba podkreślić, że Autorzy nie ograniczyli się do ukazania obowiązujących przepisów konstytucji, uzupełnili je unormowaniami ustawowymi i pochodzącymi z regulaminów parlamentarnych. Rozważania prawne często wzbogacone zostały prezentacją stanowiska doktryny (np. Rosja), orzeczeń Sądu Konstytucyjnego (np. Litwa), czy praktyki politycznej tam, gdzie doszło do egzekwowania odpowiedzialności konstytucyjnej (np. Rumunia). Warstwa informacyjna często wzbogacona została eksplikacją ustanawianych regulacji oraz ich oceną. Pewną słabością pracy, z punktu widzenia recenzenta zainteresowanego problematyką odpowiedzialności, jest brak analitycznego podejścia do niektórych zagadnień. Z uwagi na ilość zaprezentowanych państw niektó- 
re problemy zostały przedstawione w sposób skrótowy, niekiedy wręcz sygnalizacyjny. Wydaje się zresztą, że taki był zamysł twórców książki, w celu ograniczenia i tak znacznej obszerności dzieła, zadecydowali o przyjęciu formuły syntetycznych prezentacji regulacji odpowiedzialności konstytucyjnej, ale we wszystkich państwach europejskich. Po drugie, kompleksowość ujęcia sprawiła zróżnicowaną objętość poszczególnych rozdziałów. Wynika to z faktu, że rozwiązania konstytucyjno-prawne państw europejskich nie zawsze przyjmują jakiekolwiek formy odpowiedzialności konstytucyjnej (np. Bośnia i Hercegowina) bądź odpowiedzialności konstytucyjnej określonych organów (np. członków rządu w Irlandii). Warty odnotowania jest fakt, że autorzy artykułowali brak stosownych rozwiązań, a często podejmowali próbę uzasadnienia tego stanu rzeczy (np. Białoruś). Po trzecie, wyjątkowo interesujące wydają się rozważania dotyczące odpowiedzialności konstytucyjnej monarchów, spośród których niektórzy, wbrew powszechnemu przekonaniu o ich politycznej i konstytucyjnej nieodpowiedzialności, ponoszą ją w różnych, nietypowych formach (np. monarcha Danii czy Liechtensteinu).

Na szczególną uwagę zasługuje dobór Autorów poszczególnych rozdziałów. Są to niewątpliwie znawcy systemów przedstawianych państw, specjalizujący się w podjętej problematyce. Poszczególne rozdziały zostały więc napisane przez osoby kompetentne, i dotyczy to zarówno wybitnych polskich konstytucjonalistów, jak i młodych badaczy. Wśród Autorów wyróżnić należy tych reprezentujących rodzimy konstytucjonalizm opisywanego państwa: Jana Filipa (Czechy), Armanasa Abramaviciusa (Litwa), Jelenę Kondratiewą-Bryzik (Rosja), Petro Stetciuka (Ukraina) i Tomasza Majercaka (Słowacja), a także tych których pomoc okazała się istotna dla poziomu merytorycznego rozdziałów, których twórcami byli polscy naukowcy, czyli: prof. Gian Candido De Martina (Uniwersytet LUISS) z Włoch oraz prof. M. Luts-Sootaka (Uniwersytet w Tartu) i M. Ernitsa (Biuro Kanclerza Sprawiedliwości w Tallinie) z Estonii, a także prof. Mircea Criste (Zachodni Uniwersytet w Timisoarze) z Rumunii. Rozdziały ich autorstwa pokazują ujęcie problematyki odpowiedzialności konstytucyjnej z punktu widzenia doktryny danego państwa, co znacznie wzbogaca recenzowaną książkę. Można na przykład dowiedzieć się, co wydaje się dość osobliwe, że zgodnie z Konstytucją Republiki Litewskiej odpowiedzialność konstytucyjna obejmuje zwolnienie ze stanowiska nominowanych lub wybieranych przez Sejmas urzędników po wyrażeniu wobec nich wotum nieufności czy dymisję rządu, premie- 
ra i ministrów (str. 165). I chociaż w polskiej doktrynie odpowiedzialność konstytucyjna jest wyraźnie oddzielona od politycznej, a w polskich opracowaniach można znaleźć szersze ukazanie stanowiska doktryny rosyjskiej ${ }^{4}$, udział tych Autorów należy ocenić ze wszech miar pozytywnie.

Dużym walorem recenzowanej książki jest zgromadzony w niej wykaz źródeł. Autorzy opracowali i umieścili na końcu każdego rozdziału wyczerpujący katalog aktów prawnych i literatury, także obcojęzycznej. Zbiory te mogą stanowić podstawę dalszych studiów i dociekań.

Reasumując należy raz jeszcze podkreślić, że recenzowana książka jest rzetelną, interesującą i ze wszech miar godną polecenia prezentacją zagadnień form odpowiedzialności konstytucyjnej w państwach europejskich. Jest cennym źródłem wiedzy nie tylko dla naukowców, teoretyków czy osoby zainteresowane tą problematyką, ale przede wszystkim dla studentów. Posiada bowiem ogromne walory popularyzatorskie i dydaktyczne, gdyż dostarcza wiedzy i informacji o przyjmowanych w Europie rozwiązaniach instytucjonalnych, może więc być przydatna dla poszerzenia znajomości tytułowej instytucji, jak i przy pisaniu prac licencjackich i magisterskich.

Bożena Dziemidok-Olszewska (Uniwersytet Marii Curie-Skłodowskiej)

4 Por. J. Zaleśny, Odpowiedzialność konstytucyjna w Federacji Rosyjskiej, [w:] Federacja Rosyjska 1991-2001, pod red. J. Adamowskiego, A. Skrzypka, Warszawa 2002, s. 127-188. 